\title{
Diseases of Cymbopogon citratus (Poaceae) in China: Curvularia nanningensis sp. nov.
}

\author{
Qian Zhang', Zai-Fu Yang', Wei Cheng'2, Nalin N. Wijayawardene ${ }^{3}$, \\ Kevin D. Hyde ${ }^{4}$, Zhuo Chen ${ }^{5}$, Yong Wang'
}

I Department of Plant Pathology, Agriculture College, Guizhou University, Guiyang, Guizhou Province, 550025, China 2 Department of Practaculture Science, Animal Science College, Guizhou University, Guiyang, Guizhou 550025, China 3 Center for Yunnan Plateau Biological Resources Protection and Utilization, College of Biological Resource and Food Engineering, Qujing Normal University, Qujing, Yunnan 655011, China 4 Center of Excellence in Fungal Research and School of Science, Mae Fah Luang University, Chiang Rai, 57100, Thailand $\mathbf{5}$ Key Laboratory of Green Pesticide and Agricultural Bioengineering, Ministry of Education, Guizhou University, Guiyang 550025, China

Corresponding author:Zhuo Chen (gychenzhuo@aliyun.com), Yong Wang (yongwangbis@aliyun.com)

Academic editor: Huzefa Raja | Received 11 December 2019 | Accepted 30 January 2020 | Published 13 February 2020

Citation: Zhang Q, Yang Z-F, Cheng W, Wijayawardene NN, Hyde KD, Chen Z, Wang Y (2020) Diseases of Cymbopogon citratus (Poaceae) in China: Curvularia nanningensis sp. nov. MycoKeys 63: 49-67. https://doi. org/10.3897/mycokeys.63.49264

\begin{abstract}
Five Curvularia strains isolated from diseased leaves of lemongrass (Cymbopogon citratus) in Guangxi Province, China, were examined. NCBI-Blast searches of ITS sequences suggested a high degree of similarity (99-100\%) to Curvularia akaii, C. akaiiensis, C. bothriochloae, C. heteropogonis and C. sichuanensis. To accurately identify these strains, we further analysed their morphology and phylogenetic relationships based on combinations of ITS, GAPDH, and tefl gene sequences. Morphological observations indicated that the key character differing from similar species was conidial size, whereas phylogenetic analyses indicated that the five strains represent one species that is also distinct from C. akaii, C. akaiiensis and C. bothriochloae by conidial size and conidiophore length. Thus, the strains examined are found to represent a new species described herein as Curvularia nanningensis. The pathogenicity test on the host and detached leaves confirmed the new species to be pathogenic on Cymbopogon citratus leaves. Standardised requirements for reliable identification of Curvularia pathogens are also proposed.
\end{abstract}

\section{Keywords}

Cymbopogon, phylogeny, plant disease, Pleosporaceae, taxonomy

Copyright Qian Zhang et al. This is an open access article distributed under the terms of the Creative Commons Attribution License (CC BY 4.0), which permits unrestricted use, distribution, and reproduction in any medium, provided the original author and source are credited. 


\section{Introduction}

Cymbopogon citratus Stapf (lemongrass), believed to be a native of Malaysia, is now widely distributed in all continents and particularly in America, China, Guatemala and Southeast Asia. Essential oil from lemongrass is often used in aromatherapy (Williamson et al. 1996; Noel et al. 2002; Yang and Lei 2005; Shah et al. 2011). As a traditional Chinese medicine, lemongrass is known to provide relief from a variety of ailments including eczema, cold, headache and stomach-ache (Zhou et al. 2011). Guatemala is known to be the main exporter of lemongrass with about 250 tons per year. China produces 80 to 100 tons of lemongrass annually and the USA and Russia each imports about 70 tons per year (DAFF 2012). Depending on climatic conditions, lemongrass can be severely infected with a rust disease caused by Puccinia nakanishikii Dietel in Hawaii and California (Gardner 1985; Koike and Molinar 1999). In Brazil, a rust on lemongrass caused by another Puccinia species named P. cymbopogonis Massee has been reported (Vida et al. 2006). Joy et al. (2006) summarised the various disease symptoms and their causal agents of lemongrass.

Curvularia spp. infect many herbaceous plants including Cymbopogon Spreng. (Smith et al. 1989). Helminthosporium cymbopogi C.W. Dodge (三 Curvularia cymbopogonis (C.W. Dodge) J.W.Groves \& Skolko) is responsible for a severe disease of lemongrass in the lowlands of Guatemala (Dodge 1942). Barua and Bordoloi (1983) discovered C. verruciformis causing disease on Cymbopogon flexuosus Stapf. Curvularia andropogonis (Zimm.) Boedijn led to foliage blight of Cymbopogon nardus (L.) Rendle in the Philippines (Sato and Ohkubo 1990). Thakur (1994) reported C. lunata (Wakker) Boedijn as the causal agent of a new blight disease of Cymbopogon martini (Roxb.) Wats. var. motia Burk. Chutia et al. (2006) discovered that a leaf blight of Cymbopogon winterianus Jowitt is caused by Curvularia spp., resulting in a dramatic change in oil yield and its constituents. Recently, Santos et al. (2018) characterised the morphological and molecular diversity of the isolates of $C$. lunata, associated with Andropogon Linn. seeds.

Starting in 2010, there have been outbreak reports of pathogenic Curvularia in Asian countries, especially India and Pakistan (Pandey et al. 2014; Avasthi et al. 2015; Majeed et al. 2015). As China is a neighbouring country, we felt obligated to evaluate the potential threat of Curvularia to our crops. A severe Curvularia leaf blight disease was observed in three farms of Curcuma aromatica Salisb. in Hainan Province during 2010 (Chen et al. 2013). Gao et al. (2012) reported a new rice black sheath spot disease caused by $C$. fallax Boedijn in Hunan Province. Our research group is also conducting a disease survey on the occurrence of Curvularia diseases in Southwest China since 2017. Two new pathogens (C. asianensis Manamgoda, L. Cai \& K.D. Hyde and C. microspora Y. Liang, K.D. Hyde, J. Bhat \& Yong Wang bis), which affected Epipremnum pinnatum (L.) Engl. and Hippeastrum rutilum Herb. (Liang et al. 2018; Wang et al. 2018), respectively, were found.

Meanwhile, a severe leaf blast disease on lemongrass was found in Guangxi Province, China, that first appeared on the tips of leaves. As the infection progressed, more than $30 \%$ of leaves showed different degrees of abnormalities, while in the later stages 
more than $50 \%$ of the upper leaves appeared diseased and disease incidence reached $80 \%$ or above in the lower leaf blades. We provide a detailed morphological description and phylogenetic analyses of the pathogen confirming it as a new Curvularia species. Koch's postulates (see later text) have been carried out to confirm its pathogenicity. Our study provides a further understanding of Curvularia disease on lemongrass in China.

\section{Materials and methods}

Isolation

Leaves of Cymbopogon citratus showing leaf blast symptoms were collected from Guangxi Medicinal Botanical Garden in Nanning, China, during 2017. Diseased leaf pieces were surface disinfected with $70 \%$ ethanol for $30 \mathrm{~s}, 1 \% \mathrm{NaClO}$ for $1 \mathrm{~min}$ and repeatedly rinsed in sterile distilled water for 30 s. For isolation of Curvularia, conidia were removed from the diseased tissue surface using a sterilised needle and placed in a drop of sterilised water followed by microscopic examination. The spore suspension was drawn with a Pasteur pipette and transferred to a Petri dish with $2 \%$ water agar (WA) or $2 \%$ malt extract agar (MEA) and $100 \mathrm{mg} / \mathrm{l}$ streptomycin to inhibit the growth of bacteria. The plates were incubated for $24 \mathrm{~h}$ in an incubator $\left(25^{\circ} \mathrm{C}\right)$ and examined for single spore germination under a dissecting microscope. Germinating conidia were transferred separately to new 2\% MEA plates (Chomnunti et al. 2014).

\section{Morphological studies}

Single germinated spores were transferred to PDA or MEA and incubated at $28^{\circ} \mathrm{C}$ in a light incubator with $12 \mathrm{~h}$ light/12 h darkness. Ten days later, the colony and morphological characters were recorded according to Manamgoda et al. (2011, 2012). Colony diameters on PDA and MEA were measured at 1, 3, 5 and 7 days post-inoculation and average growth rates were calculated. Conidia and conidiophores were examined using a compound microscope fitted with a digital camera (Olympus BX53). The holotype specimen is deposited in the Herbarium of the Department of Plant Pathology, Agricultural College, Guizhou University (HGUP). An ex-type culture is deposited in the Culture Collection of the Department of Plant Pathology, Agriculture College, Guizhou University, China (GUCC) and Mae Fah Luang University Culture Collection (MFLUCC) in Thailand (Table 1).

\section{DNA Extraction and Sequencing}

Fungal cultures were grown on PDA at $28^{\circ} \mathrm{C}$ until the entire Petri dish $(90 \mathrm{~mm})$ was colonised. Fresh fungal mycelia were scraped off the surface of the PDA using a sterilised scalpel. A BIOMIGA Fungus Genomic DNA Extraction Kit (GD2416, 
Table I. Sequences used for phylogenetic analysis.

\begin{tabular}{|c|c|c|c|c|}
\hline \multirow[t]{2}{*}{ Species name } & \multirow[t]{2}{*}{ Strain number } & \multicolumn{3}{|c|}{ GenBank Accession numbers } \\
\hline & & ITS & GAPDH & tef1 \\
\hline Curvularia aeria & CBS $294.61^{\mathrm{T}}$ & HE861850 & HF565450 & - \\
\hline C. affinis & CBS $154.34^{\mathrm{T}}$ & KJ909780 & KM230401 & KM196566 \\
\hline C. ahvazensis & CBS $144673^{\mathrm{T}}$ & KX139029 & MG428693 & MG428686 \\
\hline C. akaii & CBS 317.86 & KJ909782 & KM230402 & KM196569 \\
\hline C. akaiiensis & BRIP $16080^{\mathrm{T}}$ & KJ415539 & KJ415407 & KJ415453 \\
\hline C. alcornii & MFLUCC $10-0703^{\mathrm{T}}$ & JX256420 & JX276433 & JX266589 \\
\hline C. americana & UTHSC 08-3414 & HE861833 & HF565488 & - \\
\hline C. asiatica & MFLUCC $10-0711^{\mathrm{T}}$ & JX256424 & JX276436 & JX266593 \\
\hline C. australiensis & BRIP $12044^{\mathrm{T}}$ & KJ415540 & KJ415406 & KJ415452 \\
\hline C. australis & BRIP $12521^{\mathrm{T}}$ & KJ415541 & KJ415405 & KJ415451 \\
\hline C. bannonii & BRIP $16732^{\mathrm{T}}$ & KJ415542 & KJ415404 & KJ415450 \\
\hline C. beasleyi & BRIP $10972^{\mathrm{T}}$ & MH414892 & MH433638 & MH433654 \\
\hline C. beerburrumensis & BRIP $12942^{\mathrm{T}}$ & MH414894 & MH433634 & MH433657 \\
\hline C. boeremae & IMI $164633^{\mathrm{T}}$ & MH414911 & MH433641 & - \\
\hline \multirow[t]{2}{*}{ C. borreriae } & CBS 859.73 & HE861848 & HF565455 & - \\
\hline & MFLUCC 11-0422 & KP400638 & KP419987 & KM196571 \\
\hline C. bothriochloae & BRIP $12522^{\mathrm{T}}$ & KJ415543 & KJ415403 & KJ415449 \\
\hline C. brachyspora & CBS 186.50 & KJ922372 & KM061784 & KM230405 \\
\hline C. buchloes & CBS $246.49^{\mathrm{T}}$ & KJ909765 & KM061789 & KM196588 \\
\hline C. carica-papayae & CBS $135941^{\mathrm{T}}$ & HG778984 & HG779146 & - \\
\hline C. chiangmaiensis & CPC $28829^{\mathrm{T}}$ & MF490814 & MF490836 & MF490857 \\
\hline C. chlamydospora & UTHSC 07-2764 & HG779021 & HG779151 & - \\
\hline C. clavata & BRIP 61680b & KU552205 & KU552167 & KU552159 \\
\hline C. coatesiae & BRIP $24261^{\mathrm{T}}$ & MH414897 & MH433636 & MH433659 \\
\hline C. coicis & CBS $192.29^{\mathrm{T}}$ & JN192373 & JN600962 & JN601006 \\
\hline C. colbranii & BRIP $13066^{\mathrm{T}}$ & MH414898 & MH433642 & MH433660 \\
\hline C. crustacea & BRIP $13524^{\mathrm{T}}$ & KJ415544 & KJ415402 & KJ415448 \\
\hline C. cymbopogonis & CBS 419.78 & HG778985 & HG779129 & - \\
\hline C. dactyloctenicola & CPC $28810^{\mathrm{T}}$ & MF490815 & MF490837 & MF490858 \\
\hline C. dactyloctenii & BRIP $12846^{\mathrm{T}}$ & KJ415545 & KJ415401 & KJ415447 \\
\hline C. deightonii & CBS 537.70 & LT631356 & LT715839 & - \\
\hline C. ellisii & CBS $193.62^{\mathrm{T}}$ & JN192375 & JN600963 & JN601007 \\
\hline C. eragrosticola & BRIP $12538^{\mathrm{T}}$ & MH414899 & MH433643 & MH433661 \\
\hline C. eragrostidis & CBS 189.48 & HG778986 & HG779154 & - \\
\hline C. geniculata & CBS $187.50^{\mathrm{T}}$ & KJ909781 & KM083609 & KM230410 \\
\hline C. gladioli & CBS 210.79 & HG778987 & HG779123 & \\
\hline C. graminicola & BRIP $23186^{\mathrm{T}}$ & JN192376 & JN600964 & JN601008 \\
\hline C. gudauskasii & DAOM 165085 & AF071338 & - & - \\
\hline C. harveyi & BRIP $57412^{\mathrm{T}}$ & KJ415546 & KJ415400 & KJ415446 \\
\hline C. hawaiiensis & BRIP $11987^{\mathrm{T}}$ & KJ415547 & KJ415399 & KJ415445 \\
\hline C. heteropogonicola & BRIP $14579^{\mathrm{T}}$ & KJ415548 & KJ415398 & KJ415444 \\
\hline C. heteropogonis & CBS $284.91^{\mathrm{T}}$ & JN192379 & JN600969 & JN601013 \\
\hline C. hominis & CBS $136985^{\mathrm{T}}$ & HG779011 & HG779106 & - \\
\hline C. homomorpha & CBS $156.60^{\mathrm{T}}$ & JN192380 & JN600970 & JN601014 \\
\hline C. inaequalis & CBS $102.42^{\mathrm{T}}$ & KJ922375 & KM061787 & KM196574 \\
\hline C. intermedia & CBS 334.64 & HG778991 & HG779155 & - \\
\hline C. ischaemi & CBS $630.82^{\mathrm{T}}$ & JX256428 & JX276440 & - \\
\hline C. kenpeggii & BRIP $14530^{\mathrm{T}}$ & MH414900 & MH433644 & MH433662 \\
\hline C. kusanoi & CBS $137.29^{\mathrm{T}}$ & JN192381 & - & JN601016 \\
\hline C. lamingtonensis & BRIP $12259^{\mathrm{T}}$ & MH414901 & MH433645 & MH433663 \\
\hline C. lunata & CBS $730.96^{\mathrm{T}}$ & JX256429 & JX276441 & JX266596 \\
\hline C. malina & CBS $131274^{\mathrm{T}}$ & JF812154 & KP153179 & KR493095 \\
\hline C. mebaldsii & BRIP $12900^{\mathrm{T}}$ & MH414902 & MH433647 & MH433664 \\
\hline C. micropus & CBS $127235^{\mathrm{T}}$ & HE792934 & LT715859 & - \\
\hline C. microspora & GUCC $6272^{\mathrm{T}}$ & MF139088 & MF139106 & MF139115 \\
\hline C. miyakei & CBS $197.29^{\mathrm{T}}$ & KJ909770 & KM083611 & KM196568 \\
\hline C. mosaddeghii & IRAN $3131 C^{\mathrm{T}}$ & MG846737 & MH392155 & MH392152 \\
\hline C. muehlenbeckiae & CBS $144.63^{\mathrm{T}}$ & HG779002 & HG779108 & - \\
\hline
\end{tabular}




\begin{tabular}{|c|c|c|c|c|}
\hline \multirow[t]{2}{*}{ Species name } & \multirow[t]{2}{*}{ Strain number } & \multicolumn{3}{|c|}{ GenBank Accession numbers } \\
\hline & & ITS & GAPDH & tef1 \\
\hline C. neergaardii & BRIP $12919^{\mathrm{T}}$ & KJ415550 & KJ415397 & KJ415443 \\
\hline \multirow[t]{5}{*}{ C. nanningensis sp. nov. } & GUCC 11000 & MH885316 & MH980000 & MH980006 \\
\hline & GUCC 11001 & MH885317 & MH980001 & MH980007 \\
\hline & GUCC 11002 & MH885318 & MH980002 & MH980008 \\
\hline & GUCC 11003 & MH885319 & MH980003 & MH980009 \\
\hline & GUCC $11005^{\mathrm{T}}$ & MH885321 & MH980005 & MH980011 \\
\hline C. neoindica & BRIP 17439 & AF081449 & AF081406 & - \\
\hline C. nicotiae & CBS $655.74^{\mathrm{T}}=$ BRIP 11983 & KJ415551 & KJ415396 & KJ415442 \\
\hline \multirow[t]{3}{*}{ C. nodosa } & CPC $28800^{\mathrm{T}}$ & MF490816 & MF490838 & MF490859 \\
\hline & CPC 28801 & MF490817 & MF490839 & MF490860 \\
\hline & CPC 28812 & MF490818 & MF490840 & MF490861 \\
\hline C. nodulosa & CBS 160.58 & JN601033 & JN600975 & JN601019 \\
\hline C. oryzae & CBS $169.53^{\mathrm{T}}$ & KP400650 & KP645344 & KM196590 \\
\hline C. ovariicola & CBS $470.90^{\mathrm{T}}$ & JN192384 & JN600976 & JN601020 \\
\hline C. pallescens & CBS $156.35^{\mathrm{T}}$ & KJ922380 & KM083606 & KM196570 \\
\hline C. palmicola & MFLUCC 14-0404 & MF621582 & - & - \\
\hline C. papendorfii & CBS $308.67^{\mathrm{T}}$ & KJ909774 & KM083617 & KM196594 \\
\hline C. perotidis & CBS $350.90^{\mathrm{T}}$ & JN192385 & KJ415394 & JN601021 \\
\hline C. petersonii & BRIP $14642^{\mathrm{T}}$ & MH414905 & MH433650 & MH433668 \\
\hline C. pisi & CBS $190.48^{\mathrm{T}}$ & KY905678 & KY905690 & KY905697 \\
\hline C.platzii & BRIP $27703 b^{T}$ & MH414906 & MH433651 & MH433669 \\
\hline C. portulacae & CBS $239.48^{\mathrm{T}}=$ BRIP 14541 & KJ415553 & KJ415393 & KJ415440 \\
\hline C. prasadii & CBS $143.64^{\mathrm{T}}$ & KJ922373 & KM061785 & KM230408 \\
\hline C. protuberata & CBS $376.65^{\mathrm{T}}$ & KJ922376 & KM083605 & KM196576 \\
\hline C. pseudobrachyspora & CPC $28808^{\mathrm{T}}$ & MF490819 & MF490841 & MF490862 \\
\hline C.pseudolunata & UTHSC $09-2092^{\mathrm{T}}$ & HE861842 & HF565459 & - \\
\hline C. pseudorobusta & UTHSC 08-3458 & HE861838 & HF565476 & - \\
\hline C. ravenelii & BRIP $13165^{\mathrm{T}}$ & JN192386 & JN600978 & JN601024 \\
\hline C. reesii & BRIP $4358^{\mathrm{T}}$ & MH414907 & MH433637 & MH433670 \\
\hline C. richardiae & BRIP $4371^{\mathrm{T}}$ & KJ415555 & KJ415391 & KJ415438 \\
\hline C. robusta & CBS $624.68^{\mathrm{T}}$ & KJ909783 & KM083613 & KM196577 \\
\hline C. rouhanii & CBS $144674^{\mathrm{T}}$ & KX139030 & MG428694 & MG428687 \\
\hline C. ryleyi & BRIP $12554^{\mathrm{T}}$ & KJ415556 & KJ415390 & KJ415437 \\
\hline C. senegalensis & CBS 149.71 & HG779001 & HG779128 & - \\
\hline C. sesuvii & Bp-Zj $01^{\mathrm{T}}$ & EF175940 & - & - \\
\hline C. shahidchamranensis & IRAN $3133 C^{\mathrm{T}}$ & MH550084 & MH550083 & - \\
\hline C. soli & CBS $222.96^{\mathrm{T}}$ & KY905679 & KY905691 & KY905698 \\
\hline C. sorghina & BRIP $15900^{\mathrm{T}}$ & KJ415558 & KJ415388 & KJ415435 \\
\hline C. spicifera & CBS 274.52 & JN192387 & JN600979 & JN601023 \\
\hline C. sporobolicola & BRIP $23040 b^{\mathrm{T}}$ & MH414908 & MH433652 & MH433671 \\
\hline C. subpapendorfii & CBS $656.74^{\mathrm{T}}$ & KJ909777 & KM061791 & KM196585 \\
\hline C. trifolii & CBS 173.55 & HG779023 & HG779124 & - \\
\hline C. tripogonis & BRIP $12375^{\mathrm{T}}$ & JN192388 & JN600980 & JN601025 \\
\hline C. tropicalis & BRIP $14834^{\mathrm{T}}$ & KJ415559 & KJ415387 & KJ415434 \\
\hline C. tsudae & ATCC $44764^{\mathrm{T}}$ & KC424596 & KC747745 & KC503940 \\
\hline C. tuberculata & CBS $146.63^{\mathrm{T}}$ & JX256433 & JX276445 & JX266599 \\
\hline C. uncinata & CBS $221.52^{\mathrm{T}}$ & HG779024 & HG779134 & - \\
\hline \multirow[t]{4}{*}{ C. variabilis } & СРС 28813 & MF490820 & MF490842 & MF490863 \\
\hline & СРС 28814 & MF490821 & MF490843 & MF490864 \\
\hline & СРC $28815^{\mathrm{T}}$ & MF490822 & MF490844 & MF490865 \\
\hline & СРC 28816 & MF490823 & MF490845 & MF490866 \\
\hline C. verruciformis & CBS 537.75 & HG779026 & HG779133 & - \\
\hline \multirow{3}{*}{ C. verruculosa } & CBS 150.63 & KP400652 & KP645346 & KP735695 \\
\hline & СРC 28792 & MF490825 & MF490847 & MF490868 \\
\hline & СРС 28809 & MF490824 & MF490846 & MF490867 \\
\hline C. warraberensis & BRIP $14817^{\mathrm{T}}$ & MH414909 & MH433653 & MH433672 \\
\hline Bipolaris drechsleri & MUS0028 & KF500532 & KF500535 & KM093761 \\
\hline B. maydis & CBS $136.29^{\mathrm{T}}$ & AF071325 & KM034846 & KM093794 \\
\hline
\end{tabular}

Ex-type isolates were labeled with "T". 
BIOMIGA, Inc., San Diego, California, USA) was used to extract the genomic DNA. DNA amplification was performed in a $25 \mu \mathrm{l}$ reaction volume which contained $2.5 \mu \mathrm{l}$ $10 \times$ PCR buffer, $1 \mu \mathrm{l}$ of each primer $(10 \mu \mathrm{M}), 1 \mu \mathrm{l}$ template DNA, $0.25 \mu \mathrm{l}$ Taq DNA

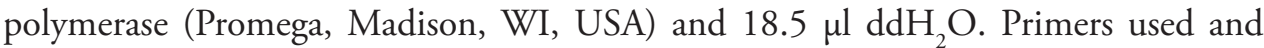
thermal cycling programme for PCR amplification of the ITS (ITS4/ITS5), GAPDH (gpd1/gpd2) and tefl (EF-526F/1567R) genes were followed as described previously (White et al. 1990; Berbee et al. 1999; Schoch et al. 2009; Liang et al. 2018).

\section{Phylogenetic analyses}

DNA sequences originated from five strains (GUCC 11000, GUCC 11001, GUCC 11002, GUCC 11003 and GUCC 11005) and reference sequences of ex-type or representative sequences of Curvularia species were downloaded from GenBank database (Table 1) with strains of Bipolaris maydis (Y. Nisik. \& C. Miyake) Shoemaker (CBS 136.29) and B. drechsleri Manamgoda \& Minnis (MUS0028) as outgroup taxa. Alignments for each locus were performed in MAFFT v7.307 online version (Katoh and Standley 2016) and manually verified in MEGA 6.06 (Tamura et al. 2013). Phylogenetic analyses were performed by Maximum Parsimony (MP), Maximum Likelihood (ML) and Bayesian methods. Sequences were optimised manually to allow maximum alignment and maximum sequence similarity as detailed in Manamgoda et al. (2012). MP analyses were performed in PAUP v. 4.0b10 (Swofford 2003) using the heuristic search option with 1,000 random taxa additions and tree bisection and reconnection (TBR) as the branch-swapping algorithm. Five thousand maxtrees were set to build up the phylogenetic tree. The characters in the alignment matrix were ordered according to ITS+GAPDH+tefl with equal weight, and gaps were treated as missing data. The MP phylogenetic analysis of Curvularia ITS sequences included pathogens from China, India and Pakistan and the wrong sequence (KN879930), actually belonging to Alternaria alternata (taxon:5599), was selected as the outgroup. The Tree Length (TL), Consistency Indices (CI), Retention Indices (RI), Rescaled Consistency Indices (RC) and Homoplasy Index (HI) were calculated for each tree generated. The resulting PHYLIP file was used to generate the ML tree on the CIPRES Science Gateway (https://www.phylo.org/portal2/login.action) using the RAxML-HPC2 black box with 1000 bootstrap replicates and GTRGAMMA as the nucleotide substitution model. For Bayesian inference analysis, the best model of evolution (GTR+I+G) was determined using MrModeltest v2 (Nylander 2004). Bayesian inference analysis was done using MrBayes v 3.2.6 (Ronquist et al. 2012). Bayesian analyses were launched with random starting trees for 2000000 generations and Markov chains were sampled every 1000 generations. The first 25\% resulting trees were discarded as burn-in. Alignment matrices are available in TreeBASE under the study ID 25080. 


\section{Koch's Postulate test}

To confirm the pathogenicity of the fungus, five healthy plants of Cymbopogon citratus were inoculated with $5 \mathrm{~mm}$ diameter mycelial plugs of the five isolates (GUCC 11000, GUCC 11001, GUCC 11002, GUCC 11003 and GUCC 11005) cut from the margins of 10-day-old actively growing cultures; the control was treated with sterile agar plugs. The plants were kept for two days in an illuminating incubator at $28^{\circ} \pm 3^{\circ} \mathrm{C}$. Additionally, two plants were sprayed with distilled water and kept as control under the same conditions. Both inoculated (host and detached leaves) and control plants were kept for two days in an illuminating incubator at $28 \pm 3^{\circ} \mathrm{C}$. After four days of incubation, the inoculated plants and leaves were observed for the development of symptoms (Zhang et al. 2018). Infected leaves were collected and the fungus was re-isolated using PDA medium and the ITS sequence was compared with original strains.

\section{Results}

\section{Phylogenetic analyses}

First, we compared the DNA sequence identity of ITS, GAPDH and tefl gene regions (Table 2). Among our five strains, there was only one base difference. In the ITS gene region, for $C$. akaiiensis, the base sequence was identical to our strains; only 1 difference for $C$. bothriochloae; base differences were 8 for $C$. akaii, 9 for $C$. deightonii and 5 for $C$. sichuanensis. Only $C$. heteropogonis had noticeable (25) base differences with our strains. In the GAPDH and tefl gene regions, the mutation rate of DNA bases was apparently faster than the ITS region. There were between 9 to 19 base differences in GAPDH and 3 to 8 in tefl. This means that in Curvularia, GAPDH has a faster

Table 2. DNA sequence differences between Curvularia nanningensis and related species in three gene regions.

\begin{tabular}{lcccc}
\hline \multicolumn{1}{c}{ Species } & Strain number & ITS (1-547 bp) & GAPDH (550-1031bp) & tef1 (1034-1899 bp) \\
\hline C. nanningensis & GUCC11000 & 0 & 1 & 0 \\
& GUCC11001 & 0 & 0 & 0 \\
& GUCC11002 & 0 & 1 & 0 \\
& GUCC11003 & 0 & 1 & 0 \\
& GUCC11005 & 0 & 0 & 4 \\
C. akaii & CBS 317.86 & 8 & 9 & 5 \\
C. akaiiensis & BRIP $16080^{\mathrm{T}}$ & 0 & 10 & 8 \\
C. bothriochloae & BRIP $12522^{\mathrm{T}}$ & 1 & 19 & - \\
C. deightonii & CBS 537.70 & 9 & 13 & 3 \\
C. heteropogonis & CBS $284.91^{\mathrm{T}}$ & 25 & 12 & - \\
C. sichuanensis & HSAUP II.2650-1 & 5 & - & \\
\hline
\end{tabular}

\footnotetext{
$\mathrm{T}=$ ex-type
} 


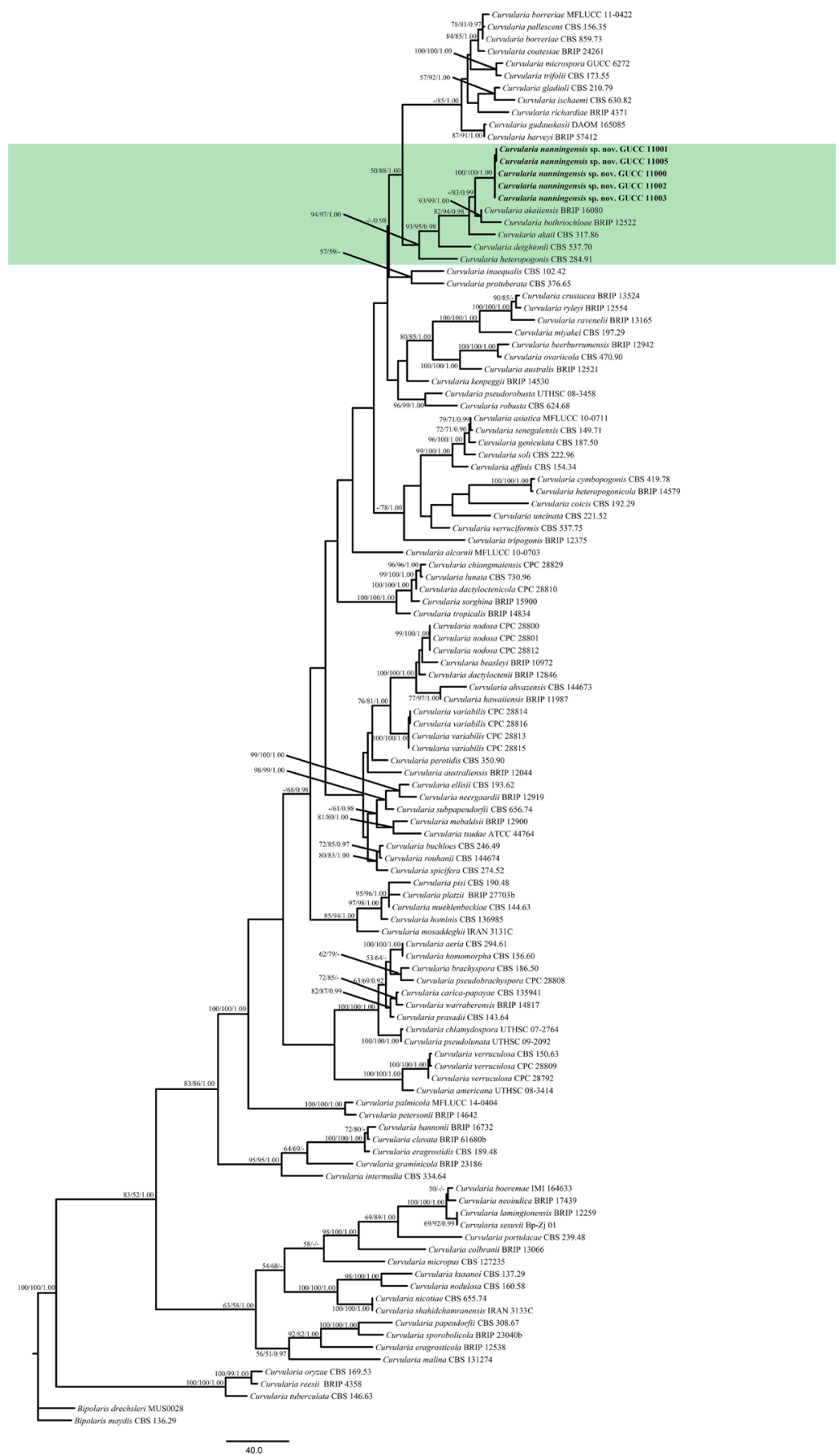

Figure I. Maximum Parsimony (MP) topology of Curvularia generated from a combination of ITS, GAPDH and tefl sequences. Bipolaris maydis (CBS 136.29) and B. drechsleri (MUS0028) were used as outgroup taxa. MP and ML above $50 \%$ and BPP values above 0.90 were placed close to topological nodes and separated by "I". The bootstrap values below 50\% and BPP values below 0.90 were labelled with "-". Our main research clade was labelled with green colour. 


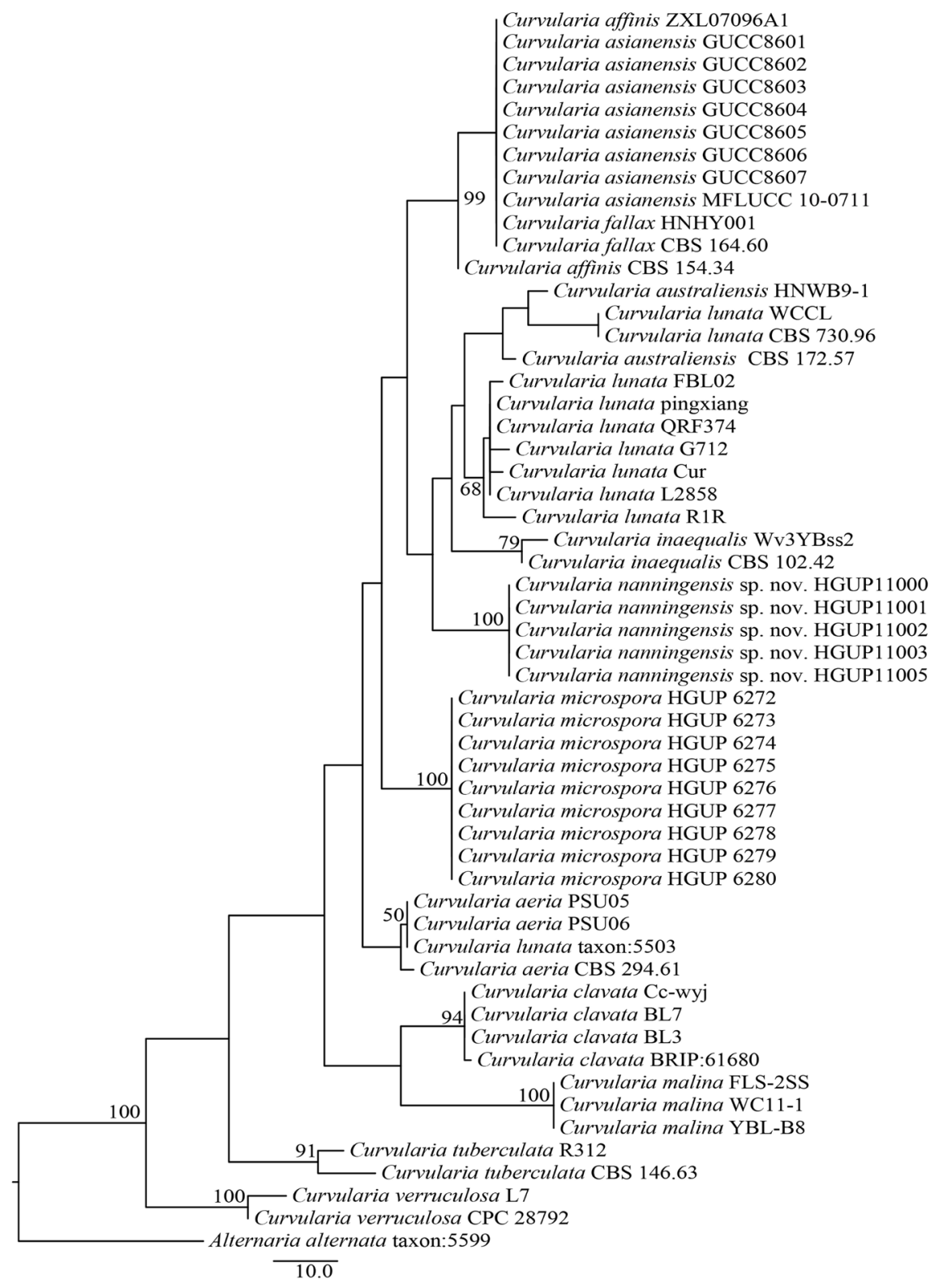

Figure 2. Maximum Parsimony (MP) analysis of Curvularia pathogens in China, India and Pakistan based on ITS sequences. Alternaria alternata (taxon:5599) was used as outgroup taxon. Bootstrap values $(\geq 50 \%)$ of the MP method are shown near the nodes.

evolutionary rate than ITS and tefl and therefore some mycologists have suggested the use of ITS+GAPDH for phylogenetic analysis and GAPDH as a secondary barcode marker for accurate identification. 
The alignment of Curvularia combining three gene fragments (ITS, GAPDH and tefl) comprised 116 strains belonging to 104 taxa. In order to accurately identify our strains, phylogenetic analysis included all ex-type and published strains of all Curvularia spp. described recently (Hyde et al. 2017; Marin-Felix et al. 2017; Dehdari et al. 2018; Heidari et al. 2018; Hernández-Restrepo et al. 2018; Mehrabi-Koushki et al. 2018; Tan et al. 2018; Jayawardena et al. 2019) which are listed in Table 1. The final alignment comprised 2032 characters (each gene fragment was separated with 2 "N") including gaps (ITS: 1-600, GAPDH: 603-1162 and tef1: 1165-2032). Among these characters, 2032 are constant, 125 variable characters are parsimony-uninformative and 503 are parsimony-informative. The parameters of the phylogenetic trees are TL $=2590, \mathrm{CI}=0.38, \mathrm{RI}=0.72$ and $\mathrm{HI}=0.62$. In the Curvularia phylogenetic tree (Figure 1), all isolates grouped together with 100\% (MP and ML) bootstrap support. Our strains (GUCC 11000, 11001, 11002, 11003 and 11005) formed a strongly supported group (MP: 100\%; ML: 100\%; BPP: 1.00) with a close relationship to C. akaii, C. akaiiensis, C. bothriochloae, $C$. deightonii and C. heteropogonis with high bootstrap support (MP: 94\%; ML: 97\%; BPP: 1.00). In this group, the five examined strains were closer to C. akaii, C. akaiiensis and C. bothriochloae and also showed high bootstrap support (MP: 82\% and ML: 94\%; BPP: 0.98).

The phylogenetic analysis of the ITS gene region evaluated all new Curvularia pathogens recently described from China, India and Pakistan. The aligned matrix consisted of fifty-four ITS sequences and included ex-type sequences of 13 Curvularia species (Supplementary Table 1). The phylogenetic tree (Figure 2) indicated that ITS BLAST searches only provided limited value for pathogenic identification. In Curvularia lunata, only one sequence WCCL (MG063428) showed a very close relationship with the ex-type strain sequence of C. lunata CBS 730.96 (MG722981). The other eight sequences were grouped into two branches, e.g. taxon:5503 (LN879926) which might belong to $C$. aeria, while the other seven formed an independent lineage. ITS sequences did not separate Curvularia affinis, C. asianensis and C. fallax and some of their sequences even clustered with C. australiensis HNWB9-1 (KT719300). After multi-gene analysis, the phylogenetic distance was shown to be unreliable and may suggest whether they belong perhaps to different species.

\section{Taxonomy}

Curvularia nanningensis Qian Zhang, K.D. Hyde \& Yong Wang bis, sp. nov. MycoBank No: 829056

Facesoffungi number: FoF 05596

Figure 3A-I

Diagnosis. Characterised by the size of conidia.

Type. China, Guangxi Province, Nanning City, Guangxi Medicinal Botanical Garden, $22^{\circ} 51^{\prime} \mathrm{N}, 108^{\circ} 19^{\prime} \mathrm{E}$, on blighted leaves of Cymbopogon citratus, 30 Septem- 

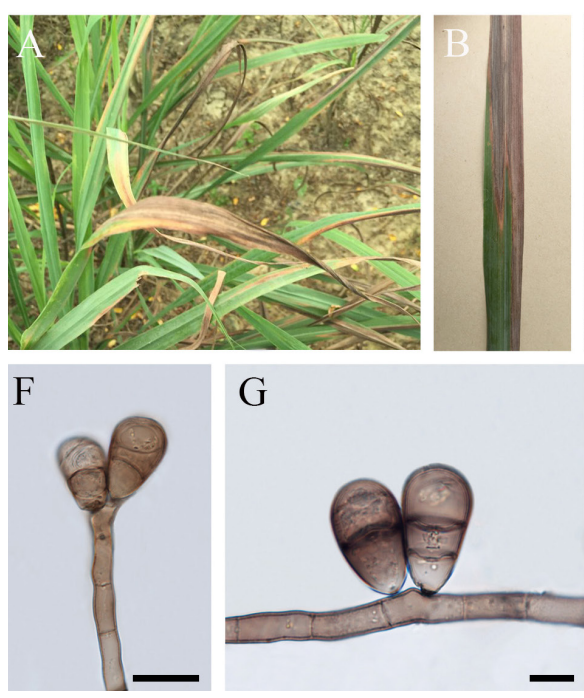

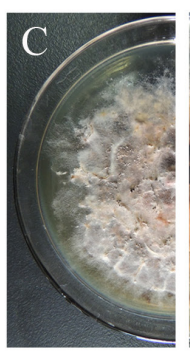

$\mathrm{H}$

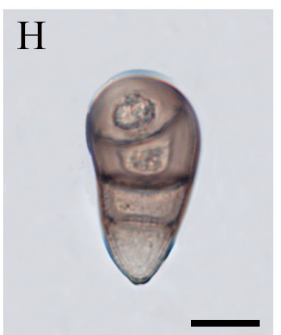

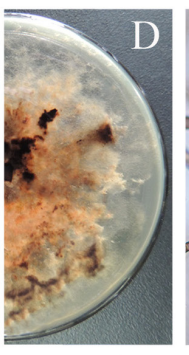

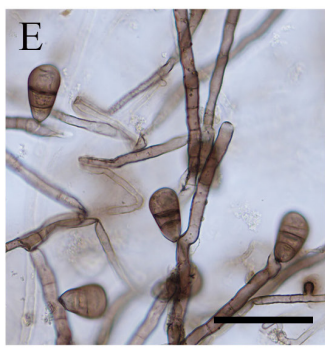

I
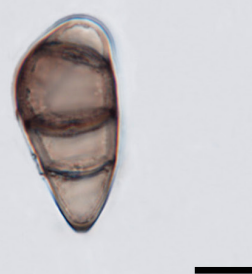

Figure 3. Curvularia nanningensis (GUCC11005, holotype) A, B diseased symptom C colony on PDA from above $\mathbf{D}$ colony on PDA from below $\mathbf{E}-\mathbf{G}$ conidia and conidiophores $\mathbf{H}-\mathbf{I}$ conidia. Scale bars: 50 $\mu \mathrm{m}(\mathbf{E}), 20 \mu \mathrm{m}(\mathbf{F}), 10 \mu \mathrm{m}(\mathbf{G}-\mathbf{I})$.

ber 2017, Q. Zhang, ZQ0091 (HGUP 11005, holotype, MFLU19-1227, isotype), GUCC 11005 and MFLUCC 19-0092, ex-type.

Description. Pathogenic on Cymbopogon citratus. Fungus initially producing white to grey lesions with dark borders on all parts of the shoot, later enlarging and coalescing over entire leaf.

Colonies on PDA irregularly circular, with mycelial growth rate $=1.0 \mathrm{~cm} /$ day, vegetative hyphae septate, branched, subhyaline to brown, smooth to verruculose, $2-3 \mu \mathrm{m}$, anastomosing. Aerial mycelium dense, felted, initially pale grey, becoming darkened and greyish-green at maturity, producing black extracellular pigments. On MEA, the colony morphology similar to PDA, with growth rate $=1.35 \mathrm{~cm} /$ day. Sexual morph: Undetermined. Asexual morph: Hyphomycetous. Conidiophores macronematous, arising singly, simple or branched, flexuous, $8-10$ septate, geniculate, pale brown to dark brown, paler towards apex, $120-200 \times 2-3 \mu \mathrm{m}(\mathrm{av} .=170 \times 2.5 \mu \mathrm{m}, \mathrm{n}=30)$. Conidiogenous cells polytretic, sympodial, terminal, sometimes intercalary, cicatrised, with thickened and darkened conidiogenous loci up to 1.0-1.2 $\mu \mathrm{m}$ diam., smooth. Mature conidia 3 to rarely 4 septa, acropleurogenous, obovoid, usually straight to curved at the slightly wider, smooth-walled, larger third cell from the base, 24.5-36.0 × 14.0-20.5 $\mu \mathrm{m}($ av. $=29.5 \times 17.5 \mu \mathrm{m}, \mathrm{n}=50)$, sub-hyaline to pale brown end cells, pale brown to dark brown at intermediate cells, with conspicuous or sometimes slightly protuberant hilum. Germination of conidia bipolar.

Distribution. China, Guangxi Province, Nanning City.

Other material examined. China, Guangxi Province, Nanning city, Guangxi Medicinal Botanical Garden, on blight leaves of C. citratus, 30 September 2017, 
Q. Zhang, ZQ0087 (HGUP 11000); ZQ0088 (HGUP 11001); ZQ0089 (HGUP 11002); ZQ0090, (HGUP 11003).

Etymology. With reference to the location, Nanning City where the fungus was isolated.

\section{Pathogenicity test}

Four days after inoculation, blast symptoms appeared on all inoculated plants, which were similar to symptoms of plants in the field (Figures 3A, B, 4A, B). Non-treated control plants remained healthy without any symptoms (Figure 4C). Curvularia nanningensis was re-isolated from the lesions of inoculated plants and the identity of the fungus was confirmed by sequencing the ITS region. Meanwhile, a detached leaf-experiment was also conducted in an illuminated incubator at $28 \pm 3^{\circ} \mathrm{C}$, where similar symptoms appeared on healthy inoculated leaves of Cymbopogon citratus after four days (Figure $4 \mathrm{D}$ right), while the control leaf (Figure $4 \mathrm{D}$ left) did not show symptoms.

\section{Discussion}

Phylogenetic analysis based on combined DNA sequences of ITS, GAPDH and tefl showed that our strains were related to three Curvularia species named C. akaii (Tsuda \& Ueyama) Sivan., C. akaiiensis Sivan. and C. bothriochloae Sivan., Alcorn \& R.G. Shivas. The main morphological characters that discriminate our strains from related species are the size-range of conidia and length of conidiophores. Curvularia bothriochloae produced conidia measuring 30-47 × 15-25 $\mu \mathrm{m}$ (Sivanesan et al. 2003) while $C$. akaiiensis produced the smallest conidia $(22.5-27.5 \times 7.5-15.5 \mu \mathrm{m})$. Conidial length of $C$. nanningensis was very close to C. akaii $(24-34 \mu \mathrm{m})$ (Tsuda and Ueyama 1985) but the conidia of our species were broader than those of C. akaii $(8.7-13.8 \mu \mathrm{m})$. Conidiophores of $C$. nanningensis were shorter than those of $C$. bothriochloae (360-425 $\mu \mathrm{m})$ (Alcorn 1990). In the case of C. sichuanensis Meng Zhang \& T.Y. Zhang, only one ITS sequence AB453881 was available in GenBank for analysis. While examining our sequences, only 4-5 bp differences were revealed in 499 bp characters between C. nanningensis and C. sichuanensis, thus indicating a close relationship between the two strains based on ITS sequence data and likely between the two species. However, according to Zhang et al. (2007), the conidial width of C. sichuanensis $(10-15 \mu \mathrm{m})$ is smaller than $C$. nanningensis $(14-20.5 \mu \mathrm{m})$ on PDA. For C. sichuanensis, the conidial wall of the median cell is deepened and thickened while $C$. nanningensis obviously does not have these characters. Meanwhile, the hilum of conidia in $C$. sichuanensis is obviously protuberant while $C$. nanningensis lacked this character.

The pathogenicity test based on natural inoculation and detached leaves (Figure 3) confirmed that Curvularia nanningensis is a pathogen of Cymbopogon citratus blast disease. We previously named our strains as $C$. cymbopogonis following a previous report of the species by Groves and Skolko (1945) as a seed-borne pathogen of Cymbopogon 

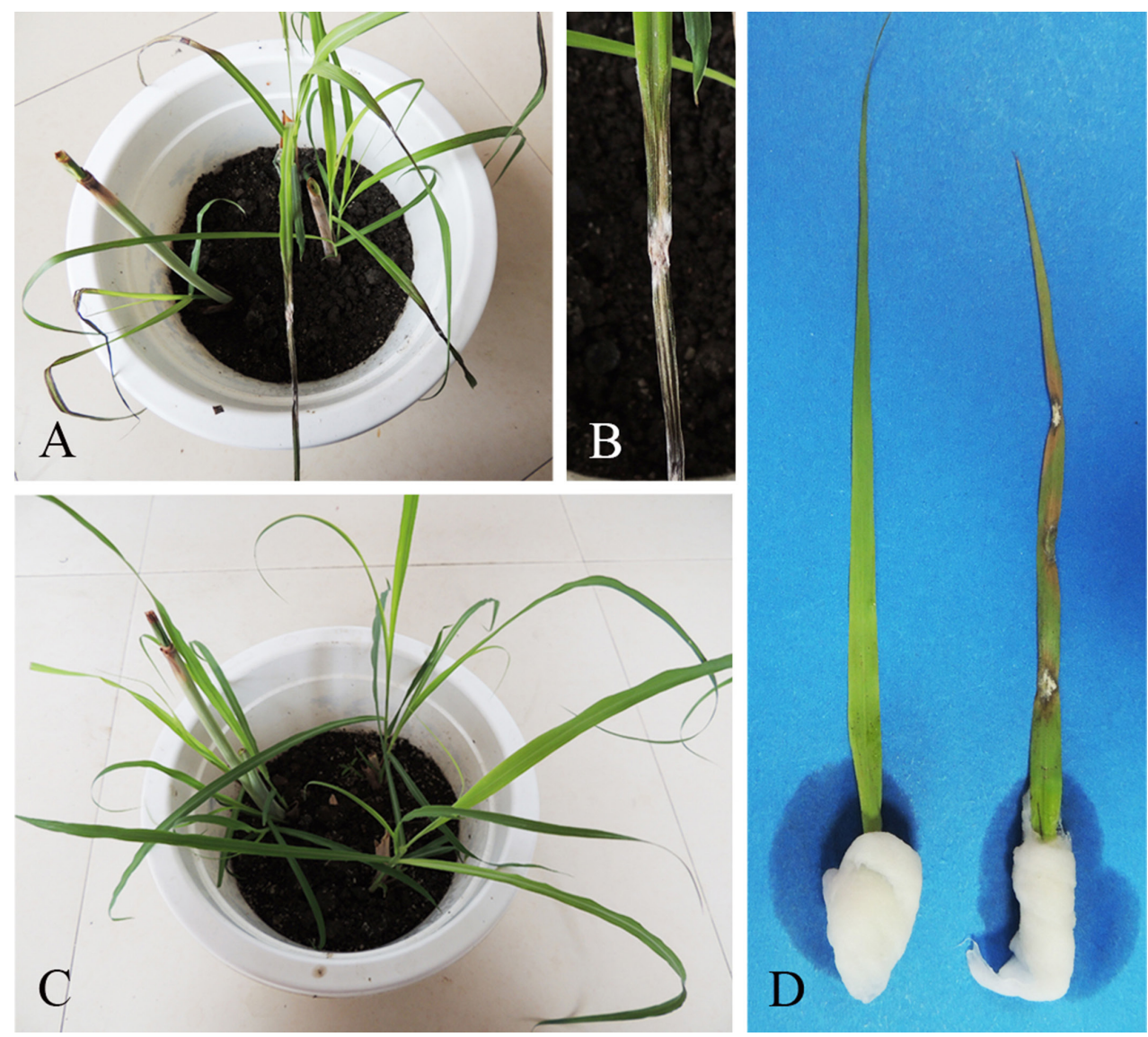

Figure 4. Pathogen inoculation and symptom (4 days). A Cymbopogon citratus inoculated and disease symptom B inoculation point and disease symptom $\mathbf{C}$ control D detached experiment. Left. Control. Right. Inoculation point and disease symptoms.

nardus. Curvularia cymbopogonis is a common pathogen which also causes diseases of sugar-cane, rice, seedlings of itchgrass, Agrostis palustris Huds. and Dactylis glomerata L. (Santamaria et al. 1971; Walker and White 1979; Olufolaji 1996; Yi et al. 2002). A single strain named C. cymbopogonis (CBS 419.78) included in our analyses grouped distant from $C$. nanningensis but its reliability seems questionable and apparently belongs to a different species (Fig. 1). We further checked the original description of this species (Groves and Skolko 1945) and found that differences in conidial shape mainly resulted from conidial width (C. cymbopogonis: $11-13 \mu \mathrm{m}$ vs $C$. nanningensis: 14-20.5 $\mu \mathrm{m})$. Additionally, Groves and Skolko (1945), Hall and Sivanesan (1972) and Yi et al. (2002) reported that C. cymbopogonis produced 4 to 5-septate conidia, whereas conidia of $C$. nanningensis only had 3-septa. Curvularia spp. are important pathogens of lemongrass. Morphological studies together with phylogenetic analyses provided evidence that $C$. nanningensis is a new pathogen distinct from all hitherto reported diseases on lemongrass. Our findings expanded the documented diversity of Cymbopogon 
pathogens within the genus Curvularia and further clarified the taxonomy of this novel pathogen, Curvularia nanningensis.

Moreover, 29 first reports of Curvularia diseases on different plants in China, India and Pakistan were found in the literature from 2010 to the present. It is evident that in this vast geographical area, Curvularia spp. have maintained a close association with plant diversity and thereby possess a rich fungal diversity that is affected by crops distribution. Among them, six reports only provided morphological data and more than half (16) only referred to ITS sequence data and morphological description (Suppl. Table 1). For unknown reasons, Iftikhar et al. (2016) misidentified the Curvularia pathogen with an Alternaria sequence (LN879930.1). Our phylogenetic tree, based on 54 reported ITS sequence data of Curvularia diseases in these countries (Figure 2), also indicated that this approach is not effective for identifying these pathogens, especially in the case of $C$. lunata as a prevalent species. However, identification of Curvularia isolates by multi-gene phylogenetic analyses has withstood scrutiny (Liang et al. 2018; Wang et al. 2018; Zhang et al. 2018). Additionally, nearly all reports, even for severe diseases, are based on a single isolate, which preclude an objective evaluation. We, therefore, propose the following standardised steps as required for the reliable identification of Curvularia diseases: 1) collect several isolates from diseased samples, 2) obtain sequences of the ITS, GAPDH and tefl or at least ITS+GAPDH for phylogenetic analysis, 3) perform BLAST searches with sequences originated from ex-type or representative strains in GenBank, and 4) combine morphological comparison and phylogenetic analysis for accurate identification.

\section{Acknowledgments}

This research is supported by the following projects: National Natural Science Foundation of China (No. 31972222, 31560489), Program of Introducing Talents of Discipline to Universities of China (111 Program, D20023), Science and Technology basic work of MOST [2014FY120100], National Key Technology Research and Development Program of the Ministry of Science and Technology of China (2014BAD23B03/03), Talent project of Guizhou Science and Technology Cooperation Platform ([2017]5788-5 and [2019]5641) and Guizhou Science, Technology Department International Cooperation Base project ([2018]5806). Nalin Wijayawardene thanks National Natural Science Foundation of China (No. NSFC 31950410558). We thank Mr Mike Skinner for linguistic editing.

\section{References}

Alcorn JL (1990) Additions to Cochliobolus, Bipolaris and Curvularia. Mycotaxon 39: 361-392. Avasthi S, Gautam AK, Bhadauria R (2015) Occurrence of leaf spot diseases on Aloe vera (L.) Burm.f. caused by Curvularia species from Madhya Pradesh, India. Biodiversitas 16(1): 79-83. https://doi.org/10.13057/biodiv/d160110 
Barua A, Bordoloi DN (1983) Record of a new disease of lemongrass (Cymbopogon flexuosus Stapf.) caused by Curvularia verruciformis Agarwal and Sahni. Current Science 52: 640-641.

Berbee ML, Pirseyedi M, Hubbard S (1999) Cochliobolus phylogenetics and the origin of known, highly virulent pathogens inferred from ITS and glyceraldehyde-3-phosphate dehydrogenase gene sequences. Mycologia 91(6): 964-977. https://doi.org/10.2307/3761627

Chen XY, Feng JD, Su Z, Sui C, Huang X (2013) First report of Curvularia leaf blight on Curcuma wenyujin caused by Curvularia clavata in China. Plant Disease 97(1): 138. https:// doi.org/10.1094/PDIS-04-12-0392-PDN

Chomnunti P, Hongsanan S, Aguirre-Hudson B, Tian Q, Persoh D, Dhami MK, Alias AS, Xu J, Liu X, Stadler M, Hyde KD (2014) The sooty moulds. Fungal Diversity 66(1): 1-36. https://doi.org/10.1007/s13225-014-0278-5

Chutia M, Mahanta JJ, Sakia RC, Baruah AKS, Sarma TC (2006) Influence of leaf blight disease on yield and its constituents of Java citronella and in vitro control of the pathogen using essential oils. World Journal of Agricultural Sciences 2(3): 319-321.

DAFF (Department: Agriculture, Forestry and Fisheries REPUBLIC OF SOUTH AFRICA) (2012) Lemongrass production. pp. 1-20.

Dehdari F, Mehrabi-Koushki M, Hayati J (2018) Curvularia shahidchamranensis sp. nov., a crude oil-tolerant fungus. Current Research in Environmental \& Applied Mycology 8: 572-584. https://doi.org/10.5943/cream/8/6/2

Dodge CW (1942) Helminthosporium spot in Citronella and lemongrass in Guatemala. Annals of the Missouri Botanical Garden 29: 127-140. https://doi.org/10.2307/2394334

Gao BD, Huang W, Xia H (2012) A new rice disease, black sheath spot, caused by Curvularia fallax in China. Plant Disease 96(8): 1224. https://doi.org/10.1094/PDIS-01-12-0021PDN

Gardner DE (1985) Lemongrass rust caused by Puccinia nakanishikii in Hawaii. Plant Disease 69(12): 1100. https://doi.org/10.1094/PD-69-1100a

Groves JW, Skolko AJ (1945) Notes on seed-borne fungi. III. Curvularia. Canadian Journal of Research 23: 94-104

Hall JA, Sivanesan A (1972) Cochliobolus state of Curvularia cymbopogonis. Transactions of the British Mycological Society 59(2): 314, 317. https://doi.org/10.1016/S00071536(72)80018-4

Heidari K, Mehrabi-Koushki M, Farokhinejad R (2018) Curvularia mosaddeghii sp. nov., a novel species from the family Pleosporaceae. Mycosphere 9(4): 635-646. https://doi. org/10.5943/mycosphere/9/4/2

Hernández-Restrepo M, Madrid H, Tan YP, da Cunha KC, Gené J, Guarro J, Crous PW (2018) Multi-locus phylogeny and taxonomy of Exserohilum. Persoonia 41: 71-108. https://doi. org/10.3767/persoonia.2018.41.05

Hyde KD, Norphanphoun C, Bazzicalupo A, Karunarathna A, Ekanayaka AH, Dissanayake A J, Soares MA, Phukhamsakda A, Wanasinghe DN, Tennakoon DS, Abdel-Aziz FA, Lee H, Siedlecki I, Senanayake IC, Manawasinghe IS, Kušan I, Yang J, Li J, Chethana KWT, Thambugala KM, He MQ, Mapook A, Clericuzio M, Dayarathne MC, Liu NG, Tian Q, Phookamsak R, Jayawardena RS, Tibpromma S, Huang SK, Hongsanan S, Konta S, 
Jayasiri SC, Abreu VP, Li V, Li WJ, Zeng XY, Xiao YP, Luo ZL, Daranagama DA, de Silva NI, Shang QJ, Perera RH, Vizzini A, Bahkali AH, Romero AI, Mešić A, Buyck B, Miller D, Camporesi E, Dovana F, Plautz HL, Promputtha I, Su HY, Bhat DJ, Jones EBG, McKenzie EHC, Kang JC, Liu JK, Xu JC, Pawłowska J, Ryvarden L, Jadan M, Wrzosek M, Berbee ML, Doilom M, Abdel-Wahab MA, Kim NK, Matočec N, Pereira O L, Chomnunti P, Zhao Q, Castañeda-Ruiz RF, Jeewon R, Zhao RL, Lumyong S, Maharachchikumbura SSN, Karunarathna SC, Boonmee S, Suetrong S, Gibertoni TB, Wen TC, Lim YW, Tkalčec Z, Liu ZY, Mortimer PE (2017) Fungal diversity notes 603-708: taxonomic and phylogenetic notes on genera and species. Fungal Diversity 87(1): 1-235. https://doi. org/10.1007/s13225-017-0391-3

Iftikhar S, Shahid AA, Ali S (2016) First report of Curvularia lunata var. aeria causing leaf blight on tomato in Pakistan. Journal of Plant Pathology 98(1): 180.

Jayawardena RS, Hyde KD, Jeewon R, Ghobad-Nejhad M, Wanasinghe DN, Liu NG, Phillips AJL, Oliveira-Filho JRC, da Silva GA, Gibertoni TB, Abeywikrama P, Carris LM, Chethana KWT, Dissanayake AJ, Hongsanan S, Jayasiri JC, McTaggart AR, Perera R H, Phutthacharoen K, Savchenko KG, Shivas RG, Thongklang N, Dong W, Wei DP, Wijayawardena NN, Kang JC (2019) One stop shop II: taxonomic update with molecular phylogeny for important phytopathogenic genera: 26-50. Fungal Diversity 94(1): 41-129. https://doi.org/10.1007/s13225-019-00418-5

Joy PP, Skaria BP, Mathew S, Mathew G, Joseph A (2006) Lemongrass: the fame of cochin. Indian Journal of Arecanut, Spices \& Medicinal Plants 2: 55-64. https://doi. org/10.1533/9781845691717.3.400

Katoh K, Standley DM (2016) A simple method to control over-alignment in the MAFFT multiple sequence alignment program. Bioinformatics 32: 1933-1942. https://doi. org/10.1093/bioinformatics/btw108

Koike ST, Molinar RH (1999) Rust Disease on Lemongrass in California. Plant Disease 83(3): 304. https://doi.org/10.1094/PDIS.1999.83.3.304D

Liang Y, Ran SF, Bhat J, Hyde KD, Wang Y, Zhao DG (2018) Curvularia microspora sp. nov. associated with leaf diseases of Hippeastrum striatum in China. MycoKeys 29: 49-61. https:// doi.org/10.3897/mycokeys.29.21122

Majeed RA, Shahid AA, Ashfaq M, Saleem MZ, Haider MS (2015) First report of Curvularia lunata causing brown leaf spots of rice in Punjab, Pakistan. Plant Disease 100(1): 219. https://doi.org/10.1094/PDIS-05-15-0581-PDN

Manamgoda DS, Cai L, Bahkali AH, Chukeatirote E, Hyde KD (2011) Cochliobolus: an overview and current status of species. Fungal Diversity 51(1): 3-42. https://doi.org/10.1007/ s13225-011-0139-4

Manamgoda DS, Cai L, McKenzie EHC, Crous PW, Madrid H, Chukeatirote E, Shivas RG, Tan YP, Hyde KD (2012) A phylogenetic and taxonomic re-evaluation of the Bipolaris-Cochliobolus-Curvularia complex. Fungal Diversity 56(1): 131-144. https://doi. org/10.1007/s13225-012-0189-2

Marin-Felix Y, Senwanna C, Cheewangkoon R, Crous PW (2017) New species and records of Bipolaris and Curvularia from Thailand. Mycosphere 8(9): 1556-1574. https://doi. org/10.5943/mycosphere/8/9/11 
Mehrabi-Koushki M, Pooladi P, Eisvand P, Babaahmadi G (2018) Curvularia ahvazensis and C. rouhanii spp. nov. from Iran. Mycosphere 9(6): 1173-1186. https://doi.org/10.5943/ mycosphere/9/6/7

Noel B, Amrine J, Kovacs A (2002) Organic treatment IPM for honey bee mites. American Bee Journal 142(5): 359-361.

Nylander J (2004) MrModeltest v2. Program distributed by the author. Evolutionary Biology Centre, Uppsala University.

Olufolaji DB (1996) Effects of some fungicides on germination, growth and sporulation of Curvularia cymbopogonis. Cryptogamie Mycologie 17(1): 47-53.

Pandey S, Kumar R, Rishi R, Giri K, Mishra G (2014). First report of Curvularia malucans causing severe leaf necrosis of Curculigo orchoides in India. Journal of Biology \& Earth Sciences 4(2): B176-B178.

Ronquist F, Teslenko M, van der Mark P, Ayres DL, Darling A, Höhna S, Larget B, Liu L, Suchard MA, Huelsenbeck JP (2012) MrBayes 3.2: efficient Bayesian phylogenetic inference and model choice across a large model space. Systematic Biology 61: 539-542. https://doi.org/10.1093/sysbio/sys029

Santamaria PA, Benoit A, Mathur SB (1971) Curvularia cymbopogonis, a hitherto unreported species pathogenic to rice in the Philippines. Plant Disease Reporter 55: 349-350.

Santos PRR, Leão EU, Aguiar RWS, Melo MP, Santos GR (2018) Morphological and molecular characterization of Curvularia lunata pathogenic to andropogon grass. Bragantia 77(2): 326-332. https://doi.org/10.1590/1678-4499.2017258

Sato T, Ohkubo H (1990) Newly discovered leaf blight of citronella grass caused by Curvularia andropogonis in the Philippines. Japan Agricultural Research Quarterly 23(3): 170-175.

Schoch CL, Sung GH, López-Giráldez F, Townsend JP, Miadlikowska J, Hofstetter V, Robbertse B, Matheny PB, Kauff F, Wang Z, Gueidan C, Andrie RM, Trippe K, Ciufetti LM, Wynns A, Fraker E, Hodkinson BP, Bonito G, Groenewald JZ, Arzanlou M, de Hoog GS, Crous PW, Hewitt D, Pfister DH, Peterson K, Gryzenhout M, Wingfield MJ, Aptroot A, Suh SO, Blackwell M, Hillis DM, Griffith GW, Castlebury LA, Rossman AY, Lumbsch H.T., Lücking R, Büdel B, Rauhut A, Diederich P, Ertz D, Geiser DM, Hosaka K, Inderbitzin P, Kohlmeyer J, Volkmann-Kohlmeyer B, Mostert L, O’Donnell K, Sipman H, Rogers JD, Shoemaker RA, Sugiyama J, Summerbell RC, Untereiner W, Johnston PR, Stenroos S, Zuccaro A, Dyer PS, Crittenden PD, Cole MS, Hansen K, Trappe JM, Yahr R, Lutzoni F, Spatafora JW (2009) The Ascomycota tree of life: a phylum-wide phylogeny clarifies the origin and evolution of fundamental reproductive and ecological traits. Systematic Biology 58(2): 224-239. https://doi.org/10.1093/sysbio/syp020

Shah G, Shri R, Panchal V, Sharma N, Singh B, Mann AS (2011) Scientific basis for the therapeutic use of Cymbopogon citratus, stapf (lemongrass). Journal of Advanced Pharmaceutical Technology and Research 2(1): 3-8. https://doi.org/10.4103/2231-4040.79796

Sivanesan A, Alcorn JL, Shivas RG (2003) Three new graminicolous species of Curvularia (anamorphic fungi) from Queensland, Australia. Australian Systematic Botany 16(2): 275-278. https://doi.org/10.1071/SB02007

Smith JD, Jackson N, Woolhouse AR (1989) Fungal Diseases of Amenity Turf Grasses, $3^{\text {rd }}$ Edn. London: E. \& F.N. Spon. 
Swofford D (2003) PAUP* - Phylogenetic analysis using parsimony (*and other methods). Version 4. Sinauer Associates, Sunderland, Massachusetts, USA.

Tan YP, Crous PW, Shivas RG (2018) Cryptic species of Curvularia in the culture collection of the Queensland Plant Pathology Herbarium. MycoKeys 35: 1-25. https:/doi. org/10.3897/mycokeys.35.25665

Tamura K, Stecher G, Peterson D, Filipski A, Kumar S (2013) MEGA6: Molecular Evolutionary Genetics Analysis version 6.0. Molecular Biology and Evolution 30: 2725-2729. https://doi.org/10.1093/molbev/mst197

Thakur RN (1994) Curvularia leaf blight - a new disease of Palma rosa. Indian Phytopathology 47: 214.

Tsuda M, Ueyama A (1985) Two new Pseudocochliobolus and a new species of Curvularia. Transactions of the Mycological Society of Japan 26: 321-330.

Vida JB, Carvalho Jr. AA, Verzignassi JR (2006) Primeira ocorrência de ferrugem em capim-limão causada por Puccinia cymbopogonis no Brasil. Summa Phytopatologica 32(1): 89-91. http://dx.doi.org/10.1590/S0100-54052006000100015

Walker HL, White JC (1979) Curvularia cymbopogonis, a pathogen of itchgrass (Rottboellia exaltata) in southern Louisiana. Plant Disease Reporter 63: 642-644.

Wang Y, Pan XJ, Zhang Q, Zhao DG (2018). First report of Curvularia asianensis, a leaf blotch disease associated with Epipremnum pinnatum in Guangxi Autonomous Region of China. Plant Disease 102(9): 1854.

White TJ, Bruns TD, Lee S, Taylor J (1990) Amplification and direct sequencing of fungal ribosomal genes for phylogenetics. In: Gelfand M, Sninsky JI, White TJ (Eds) PCR protocols: a guide to methods and applications, Academic Press, USA, 315-322. https://doi. org/10.1016/B978-0-12-372180-8.50042-1

Williamson EM, Okpako DT, Evans FJ (1996) Selection, Preparation and Pharmacological Evaluation of Plant Material. New York, UK: John Wiley \& Sons.

Yang SY, Lei Y (2005) Antimicrobial activity of Cymbopogon citratus against utilized bacteria and fungus. Journal of Shanghai Jiaotong University (Science) 23(4): 374- 382.

Yi JH, Kim JW, Lee DH, Shim GY (2002) Identification of Curvularia spp. isolated from gramineous plants in Korea. Febs Letters 30: 244-248. https://doi.org/10.4489/ KJM.2002.30.1.056

Zhang M, Wu HY, Pei ZY, Zhang TY (2007) A new species and a new variety of Curvularia in China. Southwest China Journal of Agricultural Sciences 20(5): 1144-1145.

Zhang W, Liu JX, Huo PH, Huang ZC (2018) Curvularia malina causes a foliar disease on hybrid Bermuda grass in China. European Journal of Plant Pathology 151(2): 557-562. https://doi.org/10.1007/s10658-017-1390-7

Zhou J, Xie G, Yan X (2011) Encyclopedia of Traditional Chinese Medicines - Molecular Structures, Pharmacological Activities, Natural Sources and Applications: Isolated Compounds T-z, References for Isolated Compounds Tcm Original Plants and Congeners. Berlin: Springer-Verlag. 


\section{Supplementary material I}

Table S1. Disease occurrence caused by Curvularia spp. in China, India and Pakistan

Authors: Qian Zhang, Zai-Fu Yang, Wei Cheng, Nalin N. Wijayawardene, Kevin D. Hyde, Zhuo Chen, Yong Wang

Data type: occurrence

Copyright notice: This dataset is made available under the Open Database License (http://opendatacommons.org/licenses/odbl/1.0/). The Open Database License $(\mathrm{ODbL})$ is a license agreement intended to allow users to freely share, modify, and use this Dataset while maintaining this same freedom for others, provided that the original source and author(s) are credited.

Link: https://doi.org/10.3897/mycokeys.63.49264.suppl1 